\title{
Economic Relationship between Brazil and China: An Empirical Assessment Using Sentiment and Content Analysis
}

\author{
Douglas Castro $^{1}$ (D), Danielle Mendes Thame Denny ${ }^{*}$ (1) \\ ${ }^{1}$ São Paulo Law School, Fundação Getulio Vargas, São Paulo, Brazil \\ ${ }^{2}$ Faculdade Armando Alvares Penteado and Universidade Paulista, Sao Paulo, Brazil \\ Email: douggcastro@gmail.com, ^danielle.denny@gmail.com
}

How to cite this paper: Castro, D., \& Denny, D. M. T. (2020). Economic Relationship between Brazil and China: An Empirical Assessment Using Sentiment and Content Analysis. Beijing Law Review, 11, 227-243.

https://doi.org/10.4236/blr.2020.111016

Received: January 3, 2020

Accepted: March 15, 2020

Published: March 18, 2020

Copyright $\odot 2020$ by author(s) and Scientific Research Publishing Inc. This work is licensed under the Creative Commons Attribution International License (CC BY 4.0).

http://creativecommons.org/licenses/by/4.0/

\section{(c) (i) Open Access}

\begin{abstract}
This paper uses sentiment and content analysis techniques to investigate treaties and other international documents signed by Brazil and China. It identifies the strong presence of values such as solidarity orienting their economic relations, and therefore suggests an alternative approach in observing international relations involving Global South countries, taking into consideration the Spirit of Bandung. The research used the software RStudio for text mining and ATLAS.ti for discursive analysis.
\end{abstract}

\section{Keywords}

International Law, Global South, Sentiment and Content Analysis, Spirit of Bandung

\section{Introduction}

China's economic expansion and its implication to the world economy and geopolitics provoke an intense debate among academics and politicians, specially regarding the policy actions embedded in the Vision and Actions on Jointly Building Silk Road Belt and 21 $1^{\text {st }}$-Century Maritime Silk Road (National Development and Reform Commission, Ministry of Foreign Affairs, and Ministry of Commerce of the People's Republic of China 2015). There is a broad perception that the rejuvenation of the Chinese nation is linked with China becoming a world power (Ye, 2010: p. 74).

The local impacts of the Chinese investments corroborate this, according to the China-Latin America Finance Database, in its Chinese Finance to Asian and Latin American and Caribbean: Chinese state-to-state finance tops sovereign 
lending from either the World Bank or the Inter-American Development Bank and focuses extensively on infrastructure and energy sector development (Myers \& Gallagher 2019).

Chinese policy banks are pursuing projects in Latin America as a newcomer to the Belt and Road Initiative, and an attractive market for Chinese state-owned enterprises, but it is the furthest away from China and, by many accounts, the least understood region. On the other side, many perceive the Chinese expansion to Latin America as part of an imperialistic or neocolonial project, which under the theoretical framework of Realism and Liberalism, seeks to find empirical evidence in the historical experience shared by Latin-American countries regarding their colonial encounter with great European powers (Moreira 2004; Lall, Weiss, \& Oikawa 2005; Muradian, 2006).

Recently, some argue that has been a resurgence of these colonial encounters materialized in the interferences by great powers and international institutions, "like a $19^{\text {th }}$-century colonial power; China has raged the world over to secure the resources needed to meet its ambitions" (Moyo, 2012: p. 108). By adopting this stance relating to China's expansion to Latin America, "one may describe particular events, conditions, and interactions between states without necessarily probing the nature and outcome of the processes through which state action evolves" (Snyder, 2002: p. 33). Thus, ideational variables are left off the analysis under the realist and liberal framework as grounded in material capabilities, deterministic structures, and reason alone.

Notwithstanding the relations among countries are based on premises disregarded by mainstream research agendas such as association of human beings that share ideas, identities and interests not built by deterministic forces. Therefore, the debate lacks the acknowledgment that "states are real actors to which we can legitimately attribute anthropomorphic qualities like desires, beliefs, and intentionality" (Wendt, 1999: p. 197).

So the research problem identified here is that very little is empirically known about these other forces and, in response to that, aims to use content and sentiment analyses to shed a light over some of the possibilities. This study argues that beyond the material dimension, the ideology of anti hegemonic cooperation summarized by the Spirit of Bandung permeates the economic relationship between Brazil and China.

\section{Spirit of Bandung}

The building blocks of Bandung consist of the cooperation among multiple civilizations and religions, a "trans-civilizational" perspective (Eslava, Fakhri, \& Nesiah, 2017). In 1955, a conference was held in Indonesia, to which representatives from twenty-nine nations attended. Against the European empires, Asian and African leaders forged new alliances and established anti-imperial principles for a new world order, they shared common problems such as national movements for freedom, racial issues, colonial economy, industrial development, in- 
tra-region migration. The conference came to capture the ideal of the Global South and begun to structure a practical political project to counterpoint the dominant world order for decolonization and therefore inspired a range of social movements, diplomatic efforts, institutional experiments and heterodox visions of the history and future of the world (Eslava, Fakhri, \& Nesiah, 2017).

This postcolonial solidarity, based on decentring Europe as the organizing geopolitical and cultural fulcrum of the world, but like all documents that are the result of diplomatic negotiation and compromise, was aspirational, ambiguous and limited. Even without having legally binding effect, included new subjects to the International Law, expanded legal concepts such as sovereignty, self-determination, and human rights, therefore challenging the foundations of the legal and political status quo (Eslava, Fakhri, \& Nesiah, 2017). A new postcolonial model of international legal personhood was to be invoked by these nations in their negotiations and discussions with both Western states and the Soviet Union with the idea of strategic non-alignment (Weber \& Winanti 2016).

The primary source of the Bandung Spirit is the Bandung's Conference Final Communiqué (1955), designed as a guide to principles and norms with two main axes: solidarity and resistance to deal with the relationship between multiple civilizations and religions in the world. It is based on the premise of necessary cooperation that the Third World countries seek a more equitable distribution and a broader view of development and freedoms, in a cosmopolitan localism with pluriversal global projects (not universal, nor imperialists) (Mignolo, 2017: p. 14).

Of course, material conditions are essential variables in determining behaviour in the international system, but the Bandung Spirit highlights that history has the human being as the object, in substance, however, there are two ways to consider: "first, in the mirror of a social history, and then pushed to the internal construction of the first dimension, the structure of the social laces" (Braudel, 2014: p. 174).

For this reason, the experiences shared by the countries of the Global South in their meeting with the developed countries are fundamental, or as Kishan Khoday and Leisa Perch comment, this is an intervention that aims to overcome the trinity: liberalisation, privatisation and deregulation, today's agenda for change has to be characterised by sustainable development to counter the negative distributional impacts of market-oriented reforms and globalization. Therefore reconstructing the world economy in a form conducive to sustainable, inclusive and resilient growth (Perch \& Khoday 2012).

The dichotomy between developed-developing countries that marked the world order in the post-colonial era have to make space to a more multi-polar era of global policymaking as emerging economies become shaper nations (Hitchcock, Leffler, \& Legro, 2016), the interactions between production and consumption have shifted, and pressing global and national green economy challenges present themselves ever more often (Perch \& Khoday, 2012). 
The Spirit of Bandung fits well these new multi-polar demands and is connected ontologically to the axis of solidarity among Third World countries, as summarized by Wright, Singh, and Myrdal in the book The Color Curtain: "the despised, the insulted, the hurt, the dispossessed (...) This meeting of the rejected was in itself a kind of judgment upon the Western world!" (Wright, Myrdal, \& Singh, 1995: p. 4)

Nevertheless, how to identify these variables in the relationship between Brazil and China and their power concerning the material forces and constraints of the international system itself? The main objective of this work is to find in the Brazilian case the pieces of evidence that can confirm the existence of ideational variables in the relationship with China that can refer to the presence of the Bandung Spirit, which the evidences are found in Figure 1 and Table 1.

\section{Neo-Extractive and Sustainable Development}

To explain and understand China's presence in Brazil and its implications with the recognition of the presence of the Bandung Spirit we must take into consideration foreign policies and national interests. The motivations of the approach to China by Latin American States vary according to the national interests of each country, however, three major causes can be identified: first, to achieve a

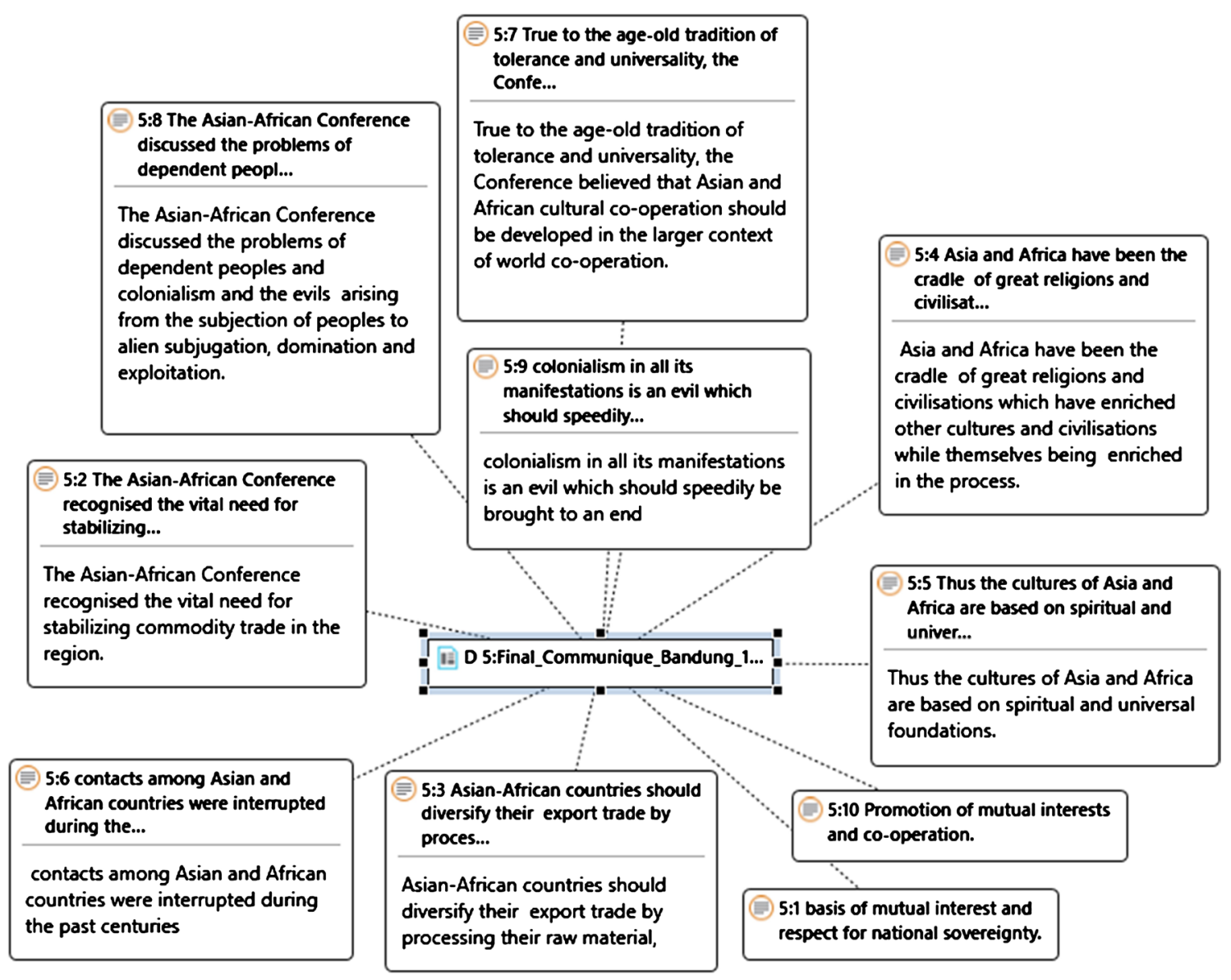

Figure 1. Network of the "Bandung Spirit" and empirical evidence (Network made by the author using ATLAS.ti). 
Table 1. Report on the empirical evidence of the presence of the "Bandung Spirit" code in the primary documents (made by the author using ATLAS.ti).

\begin{tabular}{|c|c|}
\hline CODE AND PRIMARY DOCUMENT & EVIDENCE \\
\hline 1:4 spirit of equality (1:2086 [1:2103]) - D 1: Joint Action & spirit of equality \\
\hline Plan BRAZIL and CHINA 2015-2021 & \\
\hline
\end{tabular}

1:50 Investments Third World (7:2022 [7:2098]) - D 1: encourage bilateral investments and joint investments in third countries

Joint Action Plan BRAZIL and CHINA 2015-2021

1:54 Reform financial system (8:634 [8:749]) - D 1: Joint

Action Plan BRAZIL and CHINA 2015-2021

enhance cooperation in overcoming the financial crisis and reforming the international financial system

1:57 Traditional farming practices (8:4188 [8:4387]) - D 1: WTO, FAO, UNCTAD and OIE, in order to develop a fair and strong international Joint Action Plan BRAZIL and CHINA 2015-2021 agricultural trade system and international rules that protect the interests of farmers in developing countries

2:1 South-South Cooperation (1:857 [1:1324]) - D 2: China's Foreign Aid (2014)

integrate the interests of the Chinese people with people of other countries, providing assistance to the best of its ability to other developing countries within the framework of South-South cooperation to support and help other developing countries, especially the least developed countries (LDCs), to reduce poverty and improve livelihood. China has proactively promoted international development and cooperation and played a constructive role in this aspect.

2:2 Guiding principles toward Third World Countries (1:1327 [1:1751]) - D 2: China's Foreign Aid (2014)

2:3 Millennium Development Goals_China (1:2308 [1:2449]) - D 2: China's Foreign Aid (2014)

2:4 Poverty reduction (3:566 [3:730]) - D 2: China's Foreign Aid (2014)

2:11 Loans and grants (6:3080 [6:3158]) - D 2: China's Foreign Aid (2014)

4:1 Regardless ideology (1:1427 [1:1659]) - D 4: China_Latam 2016_COHA

4:3 China-Latam (1:1886 [1:2069]) - D 4: China_Latam 2016_COHA
When providing foreign assistance, China adheres to the principles of not imposing any political conditions, not interfering in the internal affairs of the recipient countries and fully respecting their right to independently choosing their own paths and models of development. The basic principles China upholds in providing foreign assistance are mutual respect, equality, keeping promise, mutual benefits and win-win.

To promote the realization of Millennium Development Goals, China directed most of its assisting funds to low-income developing countries.

One of the important objectives of China's foreign assistance is to support other developing countries to reduce poverty and improve the livelihood of their peoples

China arranges grants (aid gratis), interest-free loans and concessional loans

However, despite the changes in Latin America that have taken place this year, Latin American countries, including those with center-right governments, are still interested in strengthening trade and investment ties with China.

From the Chinese perspective, the government has viewed the China-Latin America relationship as one based on economic benefits rather than an attempt to project political influence

export-led growth that enables development policies; second, the search for foreign direct investment to fund the development process, and third, an international alliance alternative to the one with United States and Europe.

One of the characteristics of this political trinity is the lack of concrete impact measurements at the environmental and social level (Denny, Castro, \& Yan 2017). The debate focuses more on which actor government or business keeps the rent and not on the risk that this generates in food security and in the protection of natural resources and the population (Barzola \& Baroni 2018).

One dimension that is widely used to conceptualize Chinese intervention 
abroad derives from the work of Eduardo Gudynas (2011) and can be called neo-extractive development. Though it is an old phenomenon that can be traced back to origins of capitalism and its period of conquer and colonization of the new world, it acquired new dimensions in the $21^{\text {th }}$ century.

Historically, Latin America's post-independence development strategies can be summarized into three overlapping phases: primary products extrativism (prior to the Great Depression), import substitution industrialization (roughly until the 1970s), and free market economic reforms (dominant after the debt crisis of the 1980s) (Razzaque \& Blanco 2012: p. 40). Under neo liberal orientations countries like Brazil were encouraged to export traditional primary commodities. This led to the reprimarization and to the neo-extractivism. More specifically referring to Brazilian exports to China in 2019 the numbers show an obvious clustering: soy (34\%), crude oil (24\%) and iron ore (21\%) (MDIC 2019).

The essence is the same but this new type of extrativism adds up a new massive scale and becomes central to global projects, with different types of activities, involving a myriad of national and transnational actors, and most importantly, facing the unprecedented threat of an ecological disaster.

Another point worth noticing is it pervasiveness, no matter what ideology was in charge, all Latin American governments implemented the return of a "productivist vision of development and sought to deny or conceal discussions regarding the implications (impacts, consequences, damage) of the extractive export model" (Svampa, 2019: p. 2) often justified by the argument that the export revenues will by itself finance a following social and environmental development.

This process of reprimarization and the advancement of the commodification of economies is not restricted to a region of the world but is particular important to analyse the presence of China in Brazil where "the asymmetrical economic relationship between China and Brazil has reinforced the unsustainable nature of Brazil's natural resources boom" (Raftopoulos \& Riethof, 2016: p. 153). And where Chinese direct investments in infrastructure have also become essential for environmentally and socially sensitive sectors such as the construction of hydroelectric dams that underlines the contradictions between sustainable energy sources, economic development and the rights of affected communities.

Brazil has radically reoriented its agricultural production towards monoculture exports and is rapidly becoming a mining powerhouse, opening up new sites and processors. However, the recent slowdown in the global economy has underlined the problematic nature of neo-extractivist development strategies given the changes in global prices and demand, sharpening then the social, environmental and political problems associated with this model shown by the Brazil's exports numbers mentioned above.

As a result, the incorporation of environmental and social dimensions into the economic relationship becomes a pressing issue. The rise of China can propel the development of many countries including Latin Americans, but it can also 
catalyse an escalation of social and ecological challenges (Perch \& Khoday, 2012) that will demand local policy responses and international will to balance the growing ecological footprint with the rising resource demands.

This matching becomes an opportunity if anchored in sustainable development paradigm. In terms of content analysis that is the object of this paper, the concept sustainable development is associated with documents relating to local farming practices, which in turn are associated with food security, sovereignty and biodiversity preservation, as opposed to the process of commoditizing the economy.

\section{Case Study: Sentiment and Content Analysis}

The methodology employed in this study is essential to overcome the epistemological premises Boaventura de Sousa Santos (2018) identifies in both Eurocentric critical thinking and Eurocentric conservative thinking, that is, to break the bonds that its strong influence has on the production of knowledge in terms of law and international relations, which inevitably leads the unwary to the simplistic framework of imperialism.

We do not want to relativize the production of knowledge, but to present theoretical and methodological alternatives that reject the phenomenal immediacy or pseudoconcreticity of imperialism, thus helping to explain and understand the phenomenon of China's investments in Brazil beyond its representation of enormous volumes, but to find the fundamental aspects of their essence, because, as Kosik (1976: p. 9) presage: "One thing in itself cannot manifest itself to man".

The methodological path naturally follows the objective of the work, namely to find the ideational variables such as identities, interests and/or experiences shared by Brazil and China that can demonstrate the presence of the Bandung Spirit, whose ontology is linked to solidarity.

Relations between Brazil and China date from 1881 with the signing of a bilateral trade and navigation treaty. This relationship broke up in 1949 with the onset of the People's Revolution and was resumed in 1974. According to Brazilian Ministry of Foreign Affairs, Brazil and China signed 121 bilateral treaties in various areas of interest, China has been a major source of investment and Brazil's leading trading partner since 2009. Brazil and China collaborate on successful bilateral projects in such fields as space, nanotechnology, renewable energy, among others (MRE, 2019).

Thus, the case study of relations between Brazil and China has high relevance, and also it allows preserving the "holistic and meaningful characteristics of real-life events such as individual life cycles, organizational and administrative processes, changes in urban areas, international relations, and the maturation of some sectors" (Yin, 2009: p. 13).

This case study is conducted in two steps to work with the research hypothesis and objective. In the first stage, mining procedures and sentiment analysis of se- 
lected legal texts and diplomatic speeches were conducted. In the second stage was the content analysis of legal texts and documents produced by civil society using computer-assisted qualitative data analysis software (CADQAS) called ATLAS.ti.

The use of the two steps, each with its own procedures and objectives, seeks to operationalize the sociological-legal approach that consists in the analysis of the text (letter of the law); subtext (the moral aspects of the law; deep or implicit meanings); and context (the forcible connection of law with reality) (Perry-Kessaris, 2013).

\subsection{Sentiment Analysis}

Sentiment analysis has a long history of application by academia and industry, especially in marketing-related fields, in producing consumer satisfaction-related data for a given product; the use has increased even more with the advent of social media platforms, such as Twitter and Facebook. According to Indurkhya and Damerau (2010) sentiment analysis or opinion mining is the computational study of opinions, sentiments, and emotions expressed in text.

The application of this methodology in other areas of knowledge is incipient to the point that there is no specific reference material. In this sense, the present study proposes an initial debate on best practices in the development of sentiment analysis in and related to legal texts.

In order to measure the positivity or negativity of the text to be analysed, the present study used the University of Illinois engineering department database, which contains a compilation of 2007 positive terms and 4783 negative terms. Note that 1) the fact that a word expressing opinion found in the text and database does not necessarily mean negative or positive connotation, which necessarily requires the researcher to deepen the analysis to obtain the context and subtext surrounding the term used in the text and; 2) the database is in English, which means that the primary documents used must be in the same language.

Sentiment analysis tests were performed using software RStudio and the data packages tm (text mining) and stringr (text manipulation). Mining of the texts was conducted to format the text before the analysis, with removal of spaces, signs, and numbers, lowering all words, separation of terms in characters, among other measures.

After mining, sentiment analysis was conducted from the database upload with the compilation of positive and negative lexicons, generating outputs with the number of terms found in the text comparison and the lexicons. The complexity of analysis using sentiment analysis limits, in the case that the primary source is the law, the performance of other more sophisticated tests, which does not detract from its importance and potential. In this study the most significant is to find the difference between the positive and negative pole in the analysed documents, which is aligned with Indurkhya and Damerau in the following terms: 
A rule of opinion is an implication with an expression on the left and an implied opinion on the right. The expression is a conceptual one as it represents a concept, which can be expressed in many ways in an actual sentence. The application of opinion words/phrases above can also be represented as such rules. Let Neg be a negative opinion word/phrase and Pos be a positive opinion word/phrase (Indurkhya \& Damerau, 2010: p. 21).

The list of analysed documents, the outputs, and their meanings are in the next part of the study in which the application of the methodology is made in search of empirical evidence to confirm the hypothesis. The script used in RStudio to perform mining and analysis, which in this paper represents a step or pre-analysis is available to be replicated (Castro [2019] 2019).

\subsection{Content Analysis}

This second part of the methodology is justified because of the research object that seeks explanations for behaviours associated with a notion of intentionality and awareness in the engagement between Brazil and China, that is, the existence of subjective elements that transit between the mind, the words and actions that build society and its institutions, surpassing mere quantitative considerations and claims of imperialism (Searle, 2000; Foucault, 2001; Bhaskar, 2010).

For Bardin, content analysis is a set of techniques aimed at obtaining, "by procedures, systematic and objective description of the message content, indicators (quantitative or not) that allow the inference of knowledge regarding the conditions of production/reception [...] of these messages" (Bardin, 2000: p. 37).

Perceptions of the world and of other actors diverge from reality in patterns that we can detect and for reasons that we can understand. We can find both misperceptions that are common to diverse kinds of people and important differences in perceptions that can be explained without delving too deeply into individuals' psyches. This knowledge can be used not only to explain specific decisions but also to account for patterns of interaction and to improve our general understanding of international relations (Jervis, 2017: p. 3).

The application of this search strategy is linked to the process of designating codes or labels that are assigned to words or phrases in documents, each according to its class, that represent antecedent conditions and evidence of theories that explain and/or expand knowledge and understanding about the nature and ideational variables (Krippendorff, 2012) existing in the relationship between Brazil and China, linked to the Spirit of Bandung.

Moreover, this process is permeated by the construction of inferences, which means that the analysed and coded messages go through the interpretation made by the researcher to determine states, data, and phenomena, or as Bardin (2011, p. 47) clarifies:

What one seeks to establish when conducting an analysis consciously or not 
is a correspondence between semantic or linguistic structures and the psychological or sociological structures (e.g., behaviors, ideologies, and attitudes) of utterances. In a rather metaphorical way, one will speak of a synchronic plane or horizontal plane to designate the text and its descriptive analysis, and a diachronic plane or vertical plane, which refers to the inferred variables (Bardin, 2000: p. 47).

To accomplish this task we rely on the use of CADQAS called ATLAS.ti, which in this study had a fundamental role in the organization of materials and its analysis in order to raise the search to a more abstract level with codes, meanings, and points of convergence and divergence between them vis-à-vis the elements brought by the Bandung Spirit, thus gaining traction in the generalization of the inferences made and in empirical amplitude (Gibbs, 2008).

\section{Empirical Evidences}

In this part of the paper, we will present the results of the analyses made in the selected primary documents, applying the research techniques presented above. The primary source of analysis at both stages is the Joint Action Plan 2015-2021 (MRE, 2015) signed between Brazil and China, as it presents the most up-to-date view of the two countries on themes and areas of cooperation of mutual interest, including investments and its implications.

As shown in the first line of Table 2, the sentiment analysis done in document 1 has a positivity index of $58 \%$. As noted earlier, the presence per se of positive per negative terms in documents, compared to the lexicon, does not necessarily matter in the positive or negative connotation, however, their presence evidences the approximation of the document, which materializes a universe of perceptions of cooperation and interests, from the positive or negative poles (Indurkhya \&Damerau, 2010).

In order to increase the analytical gain of this type of analysis, we have incorporated other soft and hard law documents and statements, combining expressions and commitments involving China with CELAC, BRICS, the United States, Germany, and Russia, as well as documents in which developed and in-development countries are parts of.

In the analysis we did not observe any negative result, however, regardless of the parts, the Bilateral Investment Treaties BITs have a smaller distance between the positive and negative poles and that in the other instruments that have a more generic character in terms of pronouncements and/or obligations assumed at a distance higher (in some cases more than double).

The potential existence of a BIT between China and Brazil, considering the overall index of the analysed BITs and the specific one in the case of the BIT between Brazil and Ethiopia, leads us to the conclusion of the potential repetition of the indexes. In this sense, the positivity points confirms the preference of countries for instruments that allow greater freedom in maintaining order in the international system in various areas, having a non-binding character. Soft law 
Table 2. Sentiment analysis in the selected documents. This analysis reflects how positive the language used in the documents are. It has been made using the software RStudio (for the procedures see Castro 2019).

\begin{tabular}{|c|c|c|c|c|}
\hline$\#$ & Document & Positive & Negative & Findings \\
\hline 1 & Joint Action Plan - Brazil-China - 2015-2021 & 251 & 43 & $208(58 \%)$ \\
\hline 2 & $\begin{array}{l}\text { The Second Meeting of Ministers of Foreign Affairs of the Forum of the Community of } \\
\text { Latin American and Caribbean States (CELAC) and China }\end{array}$ & 124 & 34 & $90(37 \%)$ \\
\hline 3 & $\begin{array}{l}\text { Chinese President Xi Jinping delivered on July } 25 \text { a speech titled "Keeping Abreast of the } \\
\text { Trend of the Times to Achieve Common Development" at the BRICS Business Forum }\end{array}$ & 172 & 38 & $134(45 \%)$ \\
\hline 4 & Outcome list of President Xi Jinping's state visit to the United States 2015/09/26 & 367 & 82 & $285(45 \%)$ \\
\hline 5 & $\begin{array}{l}\text { Framework Agreement for Commercial and Economic Cooperation Between Canada and } \\
\text { the European Community (1976) }\end{array}$ & 32 & 7 & $25(46 \%)$ \\
\hline 6 & BIT - China and Germany & 86 & 45 & $41(19 \%)$ \\
\hline 7 & BIT - US and Congo & 245 & 147 & $98(16 \%)$ \\
\hline 8 & BIT - China and Russia & 61 & 52 & $9(11 \%)$ \\
\hline 9 & BIT - Brazil and Ethiopia & 120 & 97 & $23(12 \%)$ \\
\hline
\end{tabular}

(Abbott \& Snidal 2000) instruments do not require a series of internalization process demanded by domestic law and present a flexible alternative for reaching international consensus and responding to dynamic needs of the developing world.

Although the Joint Action Plan Brazil-China (MRE 2015) has a considerable degree of positivity vis-à-vis other similar documents, its analysis per se fails to point out the elements in the relationship between the two countries that can confirm the presence of the Bandung Spirit's ideational variables. For this reason, in the second stage we used content analyses with the help of ATLAS.ti with the purpose of deepening the analysis and broadening the empirical coverage by confronting the Joint Action Plan Brazil-China language with other documents, namely: 1) China's Foreign Aid Report, which introduces the foundations and insights for China's participation in aid efforts to Third World countries; 2) the Chinese Investment in Brazil Report prepared by the China-Brazil Business Council, a private non-profit organization formed by private entities; and 3) the China-Latin America Report prepared by the Council On Hemispheric Affairs, which presents the academic dimension to the debate.

From the observation in Figure 2, we can identify the language of the Bandung Conference Final Communiqué (1955) and these axes of the Bandung Spirit will serve as guide in the examination of other documents studied.

The application of the solidarity and resistance axes of the Bandung Spirit in the documents: 1) Joint Action Plan 2015-2021; 2) China's Foreign Aid Report; 3) Chinese Investment in Brazil Report and 4) China-Latin America Report produces strong empirical evidence confirming the validity of the research hypothesis.

In this sense, Shaheli Das, researcher at the Center for East Asian Studies, Jawaharlal Nehru University, points out that China and Brazil have "boosted 


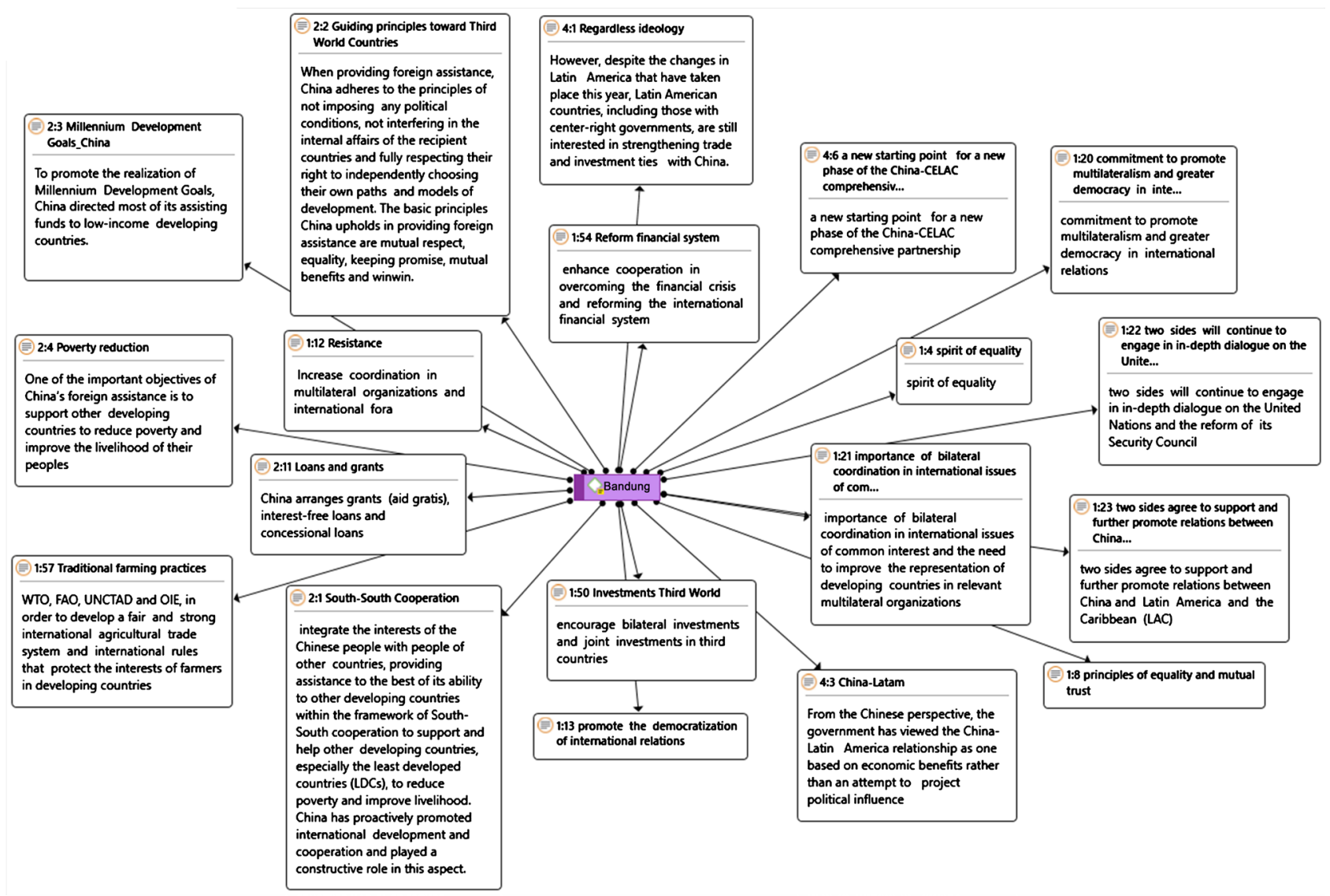

Figure 2. The "Bandung Spirit" and the axes in the Bandung's Conference Final Communiqué (1955) (network made using ATLAS.ti). Quotations extracted from the Final Comuniqué Document that show operationalization of the Bandung Spirit code.

their strategic collaboration on important international issues and in dealing with global challenges such as climate change, the international financial crisis, and to uphold the interest of developing nations" (Das, 2017).

Relating to sustainable development there are mentions in the documents from China's domestic demand axis Brazil's export growth model, which can be seen in Figure 3 in the material dimension expressed, for example, in the code "win-win results" and subjective dimension "friendship", an expression that is no longer considered as mere diplomatic rhetoric, to translate into concrete actions that can be observed in the relationship between countries, "where goals of inclusive growth and ecological sustainability are no longer peripheral considerations but central ones" (Perch \& Khoday, 2012L p. 5).

Investments in local agriculture can be factors of significant positive contribution to economic, environmental and social development in Brazil, when implemented as agreed in the documents here analysed. Linked to sustainable development, these investments can increase food security by producing and distributing a large part of production locally, thus reducing their externalities as monocultures (Denny et al., 2017).

Having China as a significant investor in Brazil [...] is the opportunity to formulate a Southern agenda on trade and environment under the framework of 


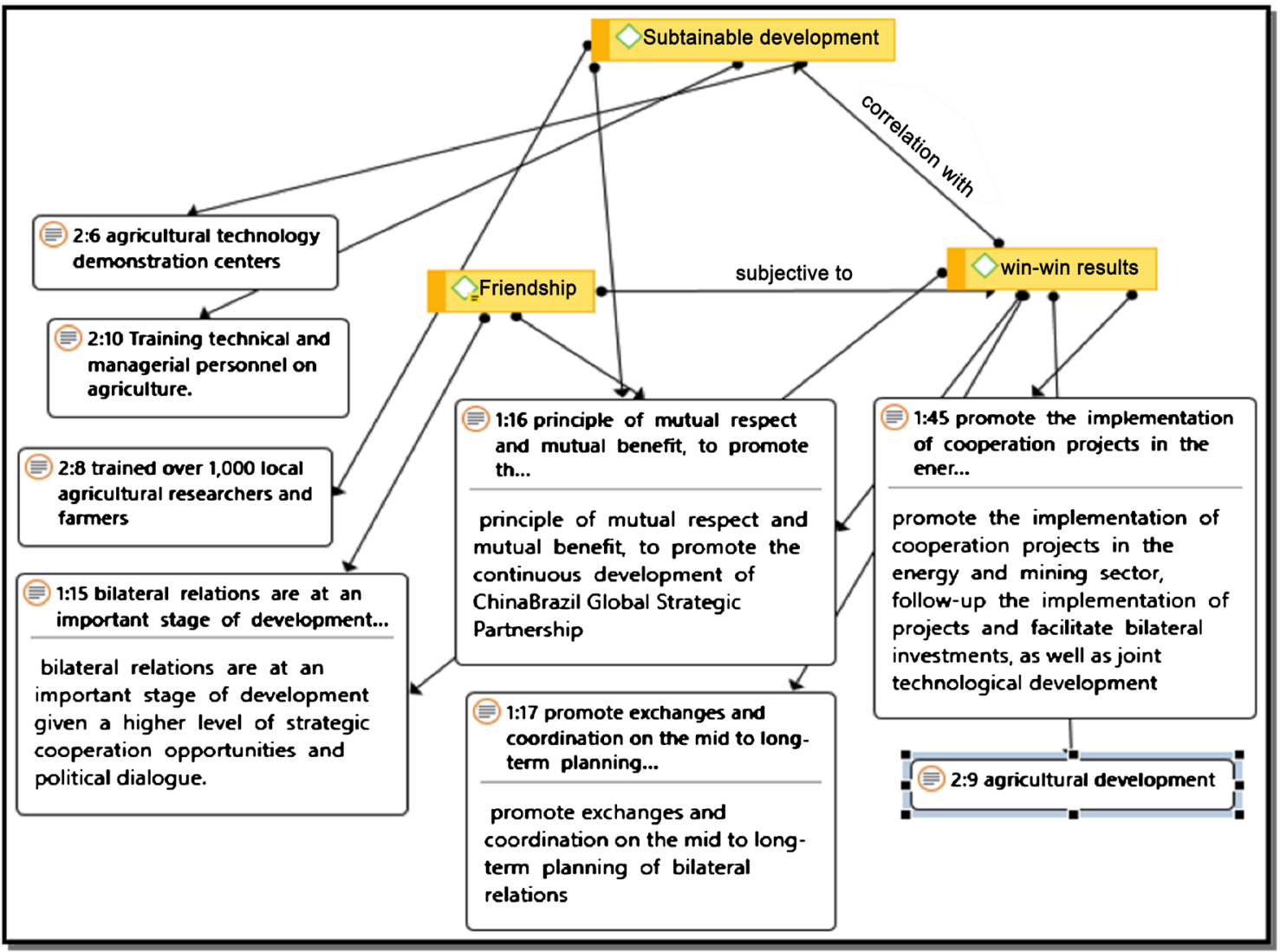

Figure 3. The "Sustainable development" code and its empirical coverage in the primary documents (made using ATLAS.ti). It reflects the solidarity dimension in the relation as there is a correlation to code "win-win results", with extensive presence in the documents.

sustainable development that integrates economic development, environmental protection, and poverty alleviation. Such an agenda would steer the trade and environment debate toward developing country concerns and away from efforts maintaining the traditional north-south impositions.

With the Doha Round of WTO negotiations at an impasse, China and Latin America should use bilateral trade and investment agreements as an opportunity to innovate and experiment rather than merely replicating the models developed by the United States and other wealthy nations (Razzaque \& Blanco, 2012: p. 74).

Enrique Dussel Peters points to the responsibility of Latin American countries to adequately prepare to follow China's movements, that is, to interrupt the speech of victimization. Latin American countries must understand the historical origin of the infrastructure projects and seek to integrate these projects with their social and productive capacity. This has to be done in a self-critical manner to spot segments of the projects into which they can be integrated through labour force, private inputs, supplier companies, or specific technologies (Peters 2018).

The China report on Latin America Lessons for South-South Cooperation and 
Sustainable Development, resonates these points mentioned by Dussel:

1) We find some cases where Chinese companies have exceeded local standards and outperformed their peers in case studies including Andes Petroleum in Ecuador, Chinalco in Peru, and Golden Dragon Affiliates in Mexico. 2) Latin American civil society has proven itself capable of holding governments and companies accountable. Non-governmental organizations (NGOs) have organized, demanded safeguards and oversight mechanisms, and mounted global campaigns against the most symbolic cases to create awareness and hold actors accountable (Ray et al. 2016).

\section{Conclusion}

The conclusion from this analysis is that the relationship between Brazil and China is consistent with the Bandung Spirit, and that the two countries considered the Brazilian vocation to concentrate exports on commodities, it was not something imposed by asymmetrical relations.

In addition, the present study points out that there are alternatives to explain and understand the economic relationship between Brazil and China that can escape from academics and politicians, as they fail to consider the ideational variables existing between these countries that are the result of shared experiences from their own in relation to the Global North.

The Bandung Spirit and its axes of solidarity and resistance provided the theoretical framework in this study, which together with the methodology adopted, managed to capture its presence in the relationship between Brazil and China.

However, considering the complexity of the phenomenon, in addition to a significant contribution to knowledge, this paper recognizes the existing methodological gaps, especially with regard to 1) a comparison of positive and negative lexicons with the terms found in the documents; and 2) examine the proportionality between the text size and the percentages of positivity or negativity found. We tried with content analysis to meet these methodological challenges, which are already part of the future research agenda of the authors.

\section{Conflicts of Interest}

The authors declare no conflicts of interest regarding the publication of this paper.

\section{References}

Abbott, K. W., \& Snidal, D. (2000). Hard and Soft Law in International Governance. International Organization, 54, 421-456. https://doi.org/10.1162/002081800551280

Bardin, L. (2000). Análise de conteúdo. Translated by Luís Antero Reto and Augusto Pinheiro, Lisboa: Edições 70.

https://edisciplinas.usp.br/pluginfile.php/4295794/mod resource/content/1/BARDlN\% 2C\%20L.\%20\%281977\%29.\%20An\%C3\%A1lise\%20de\%20conte\%C3\%BAdo.\%20Lisbo 
a $\% 20$ edi $\%$ C3\%A7\%C3\%B5es\%2C\%2070\%2C\%20225..pdf

Barzola, E. J., \& Baroni, P. A. (2018). El Acercamiento de China a América Del Sur. Profundización Del Neoextractivismo e Incremento de Conflictos y Resistencias Socioambientales. Colombia Internacional, 93, 119-145.

https://doi.org/10.7440/colombiaint93.2018.05

Bhaskar, R. (2010). Reclaiming Reality: A Critical Introduction to Contemporary Philosophy. London: Routledge. https://doi.org/10.4324/9780203843314

Braudel, F. (2014). Escritos Sobre a História (Edição: $3^{\mathrm{a}}$ ). São Paulo (SP): Perspectiva.

Castro, D. (2019). Script Used in R Studio to Perform Mining and Analysis on the Article China-Brazil. https://github.com/douggcastro/article-China-Brazil

Das, S. (2017). China-Brazil Strategic Partnership: Demystifying the Relationship. The BRICS Post (Blog).

https://www.thebricspost.com/china-brazil-strategic-partnership-demystifying-the-rela tionship

Denny, D. M. T., Castro, D., \& Yan, E. M. (2017). Agenda 2030 Measurements and Finance. Interaction of International Investment Law and Sustainability. Veredas Do Direito: Direito Ambiental e Desenvolvimento Sustentável, 14, 53-76. https://doi.org/10.18623/rvd.v14i30.1146

Denny, D. M. T., Castro, D., Witt, G., Valverde, J., \& Machado, A. R. (2017). Segurança alimentar e a governança econômica global. Revista de Direito Internacional, 14, 126-141. https://doi.org/10.5102/rdi.v14i1.3641

Eslava, L., Fakhri, M., \& Nesiah, V. (2017). Bandung, Global History, and International Law. Critical Pasts and Pending Futures. Cambridge: Cambridge University Press. https://doi.org/10.1017/9781316414880

Foucault, M. (2001). The Order of Things: Archaeology of the Human Sciences. London: Routledge. https://doi.org/10.1007/978-1-137-05194-3 5

Gibbs, G. R. (2008). Analysing Qualitative Data. Thousand Oaks, CA: SAGE Publications Ltd.

Gudynas, E. (2011). Buen Vivir: Germinando alternativas al desarrollo. América Latina en movimiento, February. https://www.alainet.org/es/active/48052

Hitchcock, W. I., Leffler, M. P., \& Legro, J. W. (2016). Shaper Nations: Strategies for a Changing World. Cambridge, MA: Harvard University Press. https://doi.org/10.4159/9780674969254

Indurkhya, N., \& Damerau, F. J. (2010). Handbook of Natural Language Processing. Chapman \& Hall/CRC Machine Learning \& Pattern Recognition Series, Boca Raton, FL: Chapman \& Hall/CRC.

Jervis, R. (2017). Perception and Misperception in International Politics. New Edition. Princeton, NJ: Princeton University Press. https://doi.org/10.2307/j.ctvc77bx3

Kosik, K. (1976). Dialectics of the Concrete: A Study on Problems of Man and World. Boston Studies in the Philosophy and History of Science, Berlin: Springer.

https://www.springer.com/gp/book/9789401197687

https://doi.org/10.1007/978-94-010-1520-2 1

Krippendorff, K. (2012). Content Analysis. An Introduction to Its Methodology(3rd ed.). London: Sage Publications, Inc.

Lall, S., Weiss, J., \& Oikawa, H. (2005). China’s Competitive Threat to Latin America: An Analysis for 1990-2002. Oxford Development Studies, 33, 163-194.

https://doi.org/10.1080/13600810500137764 
MDIC (2019). China Brazil COMEX.

http://www.mdic.gov.br/comercio-exterior/estatisticas-de-comercio-exterior/comex-vi s/frame-pais

Mignolo, W. D. (2017). Colonialidade: O lado mais escuro da modernidade. Revista Brasileira de Ciências Sociais, 32, e329402. https://doi.org/10.17666/329402/2017

Moreira, M. M. (2004). Fear of China: Is There a Future for Manufacturing in Latin America? https://doi.org/10.2139/ssrn.597141 https://papers.ssrn.com/sol3/papers.cfm?abstract id=597141

Moyo, D. (2012). Winner Take All: China's Race for Resources and What It Means for Us. London: Allen Lane.

MRE, Ministério das Relações Exteriores (2015). Joint Action Plan between the Government of the Federative Republic of Brazil and the Government of the People's Republic of China 2015-2021 in Documents Signed during the Official Visit of the Prime-Minister of the People's Republic of China, Li Keqiang, to Brazil.

http://www.itamaraty.gov.br/en/press-releases/18159-documents-signed-during-the-of icial-visit-of-the-prime-minister-of-the-people-s-republic-of-china-li-keqiang-to-brazil -may-19-2015\#pac-eng

MRE, Ministério das Relações Exteriores (2019). Celebrating 45 Years of Brazil-China Diplomatic Relations August 15, 2019. http://www.itamaraty.gov.br/en/press-releases/20818-celebrating-45-years-of-brazil-ch ina-diplomatic-relations-august-15-2019

Muradian, R. (2006). Is China a Threat to Mesoamerica's Development. Seattle Journal for Social Justice, 5, 797.

Myers, M., \& Gallagher, K. (2019). Chinese Development Finance in LAC, 2018.

National Development and Reform Commission, Ministry of Foreign Affairs, and Ministry of Commerce of the People's Republic of China (2015). Vision and Actions on Jointly Building Silk Road Economic Belt and 21st Century Maritime Silk Road. http://www.chinese-embassy.org.uk/eng/zywl/t1251719.htm

Perch, L., \& Khoday, K. (2012). China and the World: South-South Cooperation for Inclusive Green Growth.

https://www.researchgate.net/publication/283354948 China and the World South South Cooperation for Inclusive Green Growth

Perry-Kessaris, A. (2013). Socio-Legal Approaches to International Economic Law. Text, Context, Subtext. Abingdon-on-Thames: Routledge. https://doi.org/10.4324/9780203075753

Peters, E. D. (2018). Una globalización con características chinas Interview by Mariano Schuster. Nueva Sociedad.

http://nuso.org/articulo/una-globalizacion-con-caracteristicas-chinas

Raftopoulos, M., \& Riethof, M. (2016). Promoting Renewable Energy or Environmental Problems? Environmental Politics and Sustainability in Sino-Brazilian Relations. Journal of China and International Relations, 151-176.

Ray, R., Gallagher, K., López, A., \& Sanborn, C. (2016). China en América Latina: Lecciones para la cooperación Sur-Sur y el desarrollo sostenible.

http://repositorio.up.edu.pe/handle/11354/2216

Razzaque, J., \& Blanco, E. (2012). Natural Resources and the Green Economy: Redefining the Challenges for People, States and Corporations. Queen Mary Studies in International Law, Leiden: Martinus Nijhoff.

https://uwe-repository.worktribe.com/output/943489 
Santos, B. S. (2018). The End of the Cognitive Empire: The Coming of Age of Epistemologies of the South. Durham: Duke University Press Books.

Searle, J. R. (2000). Mind, Language and Society: Philosophy in the Real World. New York: Basic Books.

Snyder, C. R. (2002). Hope Theory: Rainbows in the Mind. Psychological Inquiry, 13, 249-275. https://doi.org/10.1207/S15327965PLI1304 01

Svampa, M. (2019). Neo-Extractivism in Latin America: Socio-Environmental Conflicts, the Territorial Turn, and New Political Narratives. Cambridge: Cambridge University Press. https://doi.org/10.1017/9781108752589

Weber, H., \& Winanti, P. (2016). The "Bandung Spirit" and Solidarist Internationalism. Australian Journal of International Affairs, 70, 391-406. https://doi.org/10.1080/10357718.2016.1167834

Wendt, A. (1999). Social Theory of International Politics. Cambridge: Cambridge University Press. https://doi.org/10.1017/CBO9780511612183

Wright, R., Myrdal, G., \& Singh, A. (1995). The Color Curtain. Jackson, MS: University Press of Mississippi.

Ye, Z. C. (2010). Inside China's Grand Strategy: The Perspective from the People's Republic. Translated by Steven I. Levine and Guoh Liu. Lexington, KY: University Press of Kentucky.

Yin, R. K. (2009). Case Study Research: Design and Methods, 4th Edition Applied Social Research Methods (Vol. 5). Los Angeles, CA: Sage Publications. 